\section{History of \\ Medicine}

Stafford I. Cohen, MD

Key words: Biography; cardiac pacing, artificial; heart block, complete/therapy; history of medicine, 20th century; pacemaker, artificial/history; septal defect, ventricular

From: Harvard Medical School and the Division of Cardiology, Beth Israel Deaconess Medical Center, Boston, Massachusetts 02215

Address for reprints: Stafford I. Cohen, MD, c/o Beth Israel Deaconess Medical Center, 330 Brookline Ave., Boston, MA 02215

E-mail:

scohen1@bidmc.harvard.edu

\section{On the Life \\ of Larry Graves:}

The First Child Ever to Have a Totally Implanted Pacemaker

A t 22 months of age, Larry Graves was diagnosed with a ventricular septal defect that carried a sentence of death in early childhood. At age 8 , he had corrective surgery and became the first child in the world to have a totally implanted pacemaker. Thereafter, he was hailed around the planet as "The Boy with the Electrified Heart."'

His is a story about a desperate patient, loving parents committed to saving their child at any cost, caring communities, pioneering doctors, and collaborating medical institutions.

\section{A Shaky Beginning}

Barbara Ann and Thomas Graves married young. When times were good, factories in Fairmont, West Virginia — where the family lived — provided the bulk of employment. Thomas worked full-time at Westinghouse and part-time as a bookkeeper at an automobile agency. Barbara Ann was a full-time homemaker and supplemented the family income by caring for foster children as if they were her own. ${ }^{2}$

On 27 May 1952, Barbara Ann Graves gave birth to twin boys, Larry Wayne and Barry Layne, at Fairmont General Hospital. The twins were additional responsibilities, which now included 5-year-old Sharon (the twins' older sister), 2 foster children, an automobile, and a home mortgage. A 4th child of their own, Shannon, was to follow. During trouble-free times, the family could get along. But a series of difficult problems unsettled the lives of the Graves family, whom Barbara characterized as "hard-working, middle-class, honest people."

At the outset, Larry lacked Barry's vigor, and then simply failed to thrive. Their exceptional family pediatrician suspected congenital heart disease. He recommended travel to Children's Hospital Boston because of its renowned surgical department led by Dr. Robert Gross. The advice was taken and the diagnosis made- "a hole in the heart" between the main chambers. The treatment was a not-yet-perfected openheart operation that had better outcomes among older children. So Barbara Ann and Thomas delayed Larry's surgery as long as possible. While they waited, medical expenses and biannual trips to Boston became an emotional and financial drain.

Whereas Barry grew tall, broad, and strong with powerful physical attributes (Fig. 1), Larry remained frail, became breathless during slight activity, and sat on the sidelines, envious of his brother's athletic skills.

\section{Anxious Moments}

At the age of 8 , weighing 40 pounds and failing fast, Larry returned to Boston for "hole in the heart" ventricular septal defect repair, performed on 14 October 1960 by Dr. Samuel Schuster and his team of surgeons. The surgery was immediately complicated by complete heart block. Dr. Schuster was well prepared for such an emergency. He followed a procedure proposed by Dr. Walton Lillehei of Minnesota, whose team had developed a method of emergency management that involved placing one end of a wire electrode on the heart at the conclusion of surgery. The other end of the electrode was drawn out of the body and attached to an external pacemaker. ${ }^{3}$

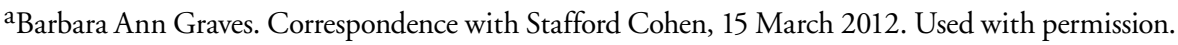

(C) 2016 by the Texas Heart ${ }^{\circledR}$ Institute, Houston 


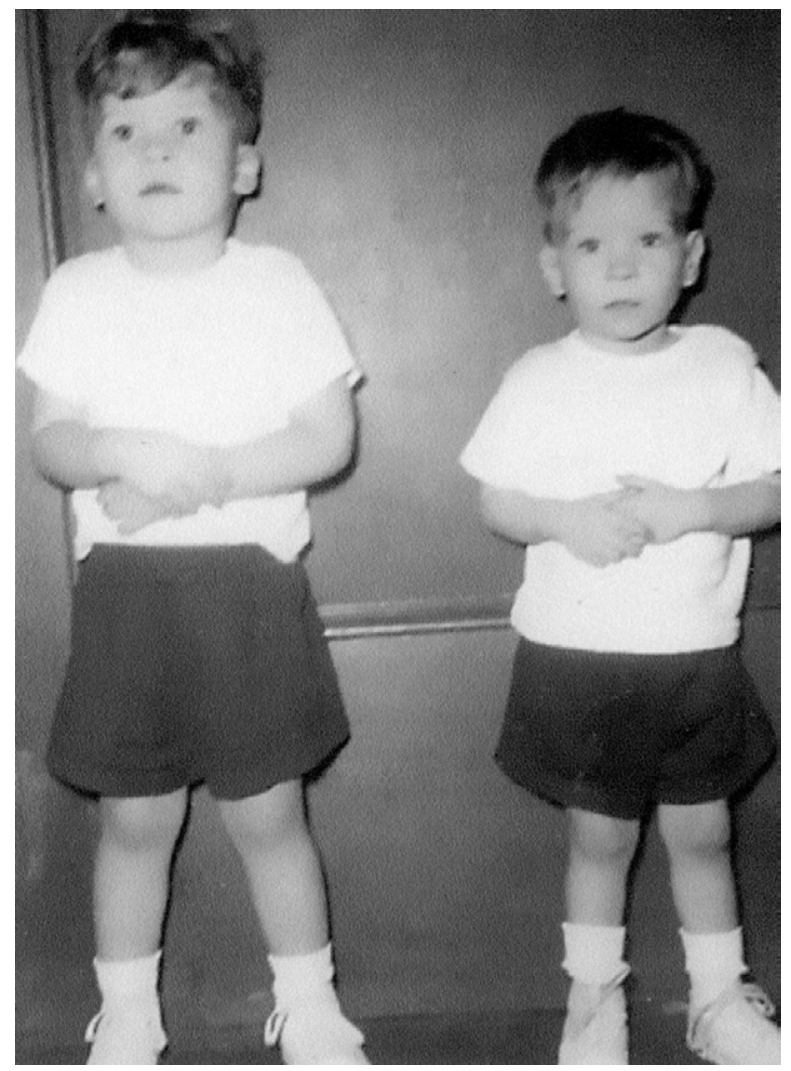

Fig. 1 The twins' 2nd-year birthday picture, 27 May 1954. Barry (left) and Larry (right). Courtesy of Barbara Ann Graves. Used with permission.

Lillehei's method had been adapted from animal experiments at Otto Kreyer's pharmacology department at Harvard Medical School, located diagonally across from Children's Hospital. ${ }^{4}$

The pediatric surgical team asked Dr. Paul Zoll at neighboring Beth Israel Hospital to consult on Larry, whose heart rate was being driven by a specialized Electrodyne monitor-automatic pacemaker with a face plate that read, "Developed by Paul M. Zoll, MD."

The surgeons and Dr. Zoll hoped that Larry's heart block would resolve, while Barbara Ann and Thomas prayed that their boy would survive. Hazardous heart block persisted. Continuous temporary pacing was impractical, unreliable, and carried a risk that the electrode would provide a portal for serious infection. After agonizing for days, the physicians developed a survival plan that entailed Larry's receiving a fully implanted pacemaker. The procedure was performed on 10 November 1960.

Paul Zoll and his colleague, thoracic surgeon Howard Frank, had performed open-chest pacemaker placements on a total of only 3 adults. ${ }^{5}$ Operating on a child would be far more complex. Drs. Frank and Schuster headed the surgical team that succeeded in restoring Larry's heart rate to normal with an electronic pacemaker. At the time, no one knew if the operation was the first of its kind on a youngster, but a recent comprehensive investigation has firmly established that Larry was the very first child in the world to receive a totally implanted, self-contained, long-term pacer. ${ }^{6}$ The operation on children remained formidable for years. In 1964, 4 years after Larry's procedure, a review of all cases revealed that only 17 children in the world had received an implanted pacemaker.

Larry Graves's immediate story captured a worldwide audience, as did its aftermath. The media continued to report on his progress, and Boston ("the hub of the universe") was fittingly the hub of news about Larry.

Workers from the local Westinghouse labor union in neighboring Hyde Park, Massachusetts, and the Sylvania local 291 International Union of Electrical Radio and Machine Workers in more distant Salem, Massachusetts, donated a total of 32 units of blood and contributed funds to defray Larry's hospital bill. ${ }^{8}$ Inmates at Massachusetts State Prison in Walpole similarly held a collection drive for Larry and sent the donated money to him in a "Pixie Bank" on Christmas with the encouraging note, "We are all in your corner pulling for you."

When hospital bills became burdensome, a bank in the Graveses' hometown of Fairmont established a fund in Larry's name. On his desktop, the good family pediatrician kept a donation fishbowl for Larry and often wrote encouraging letters to his recovering hospitalized patient. Knowing that discomfort accompanies survival surgery, Larry was reminded to "pleasantly endure the miracle of life."

Fairmont had a population of only 30,000. The local economy was depressed. Workers were idle. The bank fund received many donations of several dollars or less. Boston newspapers did their part by publishing the hospital bill and the address of Larry's fund. The response reduced the total debt.

\section{Another Crisis}

Shortly after the family returned to Fairmont, Larry fell and bruised the skin overlying the pacemaker. The site became infected and forced the family to hasten back to Children's Hospital. Sharon, Barry, Shannon, and the foster children remained in Fairmont under the care of a relative, as in the past. $^{8}$

While Larry was in early recovery, his private-duty nurse and her husband graciously offered Barbara Ann and Thomas a place to stay at their nearby home to ease their access to Larry, to increase their physical comfort, and to reduce their emotional stress. Mary and Alfred Leonard were accustomed to embracing the families of sick youngsters at Children's Hospital. a,b

\footnotetext{
aBarbara Ann Graves. Correspondence with Stafford Cohen, 15 March 2012. Used with permission.

bAlfred and Mary Leonard. Correspondence with Stafford Cohen, 6 October 2014. Used with permission.
} 
Larry's setback caused his medical bills to mount. The hospital forgave the balance after Boston newspapers erroneously reported that Barbara Ann and Thomas were destitute, were selling their furniture, and were in danger of losing their house and car. ${ }^{10,11}$ In fact, the sale of unneeded possessions was motivated by a decision to relocate to Massachusetts so that Larry could have continuous access to his doctors. The entire nuclear family moved to Wrentham, a pleasant rural community west of Boston. Barbara Ann and the foster children were heartbroken when they separated. But the move was a wise decision, because 11 additional hospitalizations caused by infection and pacemaker-system malfunction occurred during the next 24 months. Under the watchful eyes of his doctors and the healing capacity of youth, Larry gradually regained his health. After the family established a semblance of normalcy, Barbara Ann thought that "perhaps Larry was spared for a reason."

Home life didn't remain settled for long. While returning to their Wrentham neighborhood from Boston, Barbara Ann and Thomas noticed a dark column of smoke. When they arrived at Taunton Street, a police officer barred passage to their home, which was ablaze in full view. Fortunately the house was unoccupied except for a pet kitten that was rescued by the firefighters. ${ }^{12}$ When Thomas saw the conflagration up close, he said to his wife, "Don't worry, everything will be all right," and it was. The house was not destroyed, and several good neighbors temporarily sheltered members of the split-up family. The resilient couple pressed on, as was their custom. They did not regard themselves as victims, or designees for hard times. Finding temporary quarters was not an overwhelming disruption, for lives were not jeopardized.

Barbara Ann continued to help those in need. She looked after the developmentally disabled and believes that hers was the first foster home for several children with Down syndrome, who were sent from the Wrentham State School.c Thomas always welcomed disadvantaged children, for he and his brother had temporarily been sent to an orphanage when they were youngsters.

New England winters can be brutal, especially for non-natives. Larry's doctors suggested that he move south to avoid the frigid winters. After living happily in Wrentham for 9 years, Larry and his entire family moved to Florida. In time, Larry entered the work force as a cottage parent overseeing "special-needs" youngsters. ${ }^{\mathrm{c}} \mathrm{He}$ enjoyed his work because it came naturally to him. Larry was merely replicating his parents' commitment to help others.

'Barbara Ann Graves. Interview with Stafford Cohen, 23 February 2012. Used with permission.

\section{Tragedy}

In 1980, Larry, Barry, and Shannon celebrated Christmas with their parents. At the end of this joyous event, the children left to return to their individual homes. Larry then fractured a leg in an automobile accident caused by the glare of a blinding sun. Several weeks later, Barry and his girlfriend inexplicably disappeared. They remained missing for a frantic week that was the worst ever for Barbara Ann and Thomas. ${ }^{\mathrm{C}}$ It culminated with their watching a late-breaking television news report of 2 drowned occupants in a submerged car that had been lifted out of a nearby swamp. Authorities surmised that the automobile veered sharply off the road and flipped upside down into the swamp. ${ }^{13}$ What tragic irony: robust Barry, at the age of 28 , had predeceased fragile Larry.

\section{Final Days}

The surviving family members soldiered on, not permitting themselves to be totally consumed by events beyond their control, events that could not be altered. Barbara Ann and Thomas supported each other and set an example for their 3 remaining children, who "all pitched in." c At various times, Barbara reflected on her strength and that of her family: ${ }^{\text {a }}$

"I'm all right-I am strong."

"We always try to think positive and not have a negative attitude."

"Our lives were full of trying times—but good mostly."

"So much took place in our lives, we just accepted it, thinking all will soon pass, enjoy each day no matter what comes, and take care of it as best we could."

Would life-threatening or tragic events take a holiday? Not yet. Barbara Ann and Thomas were put to the test again when ill health revisited Larry in 1986 at the age of 34 . This time progressive congestive heart failure resulted in his inability to perform the job he had loved for 16 years. In nature's embrace, Larry still managed to enjoy his long-established pleasures of swimming, camping, and fishing. Three years later, symptoms became so severe that heart transplantation was contemplated. Once again a life-saving medical intervention was considered, but this time could not be implemented because Larry did not qualify as a candidate.

A sequence of pacemakers had kept Larry Graves's heart beating between 1960 and 1989, when, at age 37, he could no longer deny the Angel of Death.

This story started in Fairmont, West Virginia, had dramatic moments in Boston, Massachusetts, and ended

\footnotetext{
aBarbara Ann Graves. Correspondence with Stafford Cohen, 15 March 2012. Used with permission.
} 
in Fort Myers, Florida. It is about the life journey of Larry Graves, the first child in the world to receive a totally implanted pacemaker. He undertook the risk, and several more decades of life were the reward. With optimism, and without complaint, Larry Graves underwent 36 operative procedures, almost one for each year that he was on this earth. In 1960, a man from Buffalo, New York, and Larry were the first adult and child to receive fully implanted pacemakers. Larry, and most other recipients, experienced the complications and malfunctions of unreliable early pacemaker systems. Fortunately, the rapid evolution of technology made the devices increasingly more dependable. Larry led the way for other children, and his later years were testimony that adulthood could be achieved. In 1960, When Larry was recovering from his surgeries at Children's Hospital, a columnist at the Boston Herald wrote, "There is in his story the moral that tomorrow's science holds hope for today's chronically ill patients." Yes, little Larry led the way. He gave hope to countless children with troubled hearts. During the year he died, approximately 120,000 adults and children (combined) got pacemaker implantations in the U.S. alone.

Barbara Ann's words were prophetic when she said, "perhaps Larry was spared for a reason."

\section{References}

1. The boy with the electrified heart. Newsweek 1960 Nov 28. p. 80.

2. Sells furniture, car to pay part of boy's bill; not complaining. The Daily Courier (Connellsville, Pa), 1961 Nov 11. p. 9.
3. Weirich WL, Gott VL, Lillehei CW. The treatment of complete heart block by the combined use of a myocardial electrode and an artificial pacemaker. Surg Forum 1958;8:360-3.

4. Gott VL. Critical role of physiologist John A. Johnson in the origins of Minnesota's billion dollar pacemaker industry. Ann Thorac Surg 2007;83(1):349-53.

5. Zoll PM, Frank HA, Zarsky LR, Linenthal AJ, Belgard AH. Long-term electric stimulation of the heart for Stokes-Adams disease. Ann Surg 1961;154:330-46.

6. Cohen SI. Paul Zoll MD. The pioneer whose discoveries prevent sudden death. Salem (NH): Free People Publishing; 2014. p. 105-11.

7. Siddons H, Sowton E. Cardiac pacemakers. Springfield (Ill): Charles C. Thomas, Publisher; 1967. p. 80-3.

8. Gordon N. "Best Thanksgiving ever" for boy, 8 , with battery operated heart. Boston Herald, 1960 Nov 24. p. 16.

9. Gifts flood heart boy by admirers of pluck. Boston Daily Record, 1960 Dec 19. p. 13.

10. Hospital tears up \$2,484 bill for boy. Monessen Valley Independent (Monessen, Pa), 1961 Nov 11. Unknown page. From the scrapbook of Barbara Ann Graves; used with permission.

11. Ehrlich B (Man About Boston). A family gives thanks, but the going is rough. Boston Traveler, 1961 Nov 27. p. 16.

12. Alert neighbor helps save home in fire. The Woonsocket Call (Woonsocket, RI), 1966 Oct 3. Unknown page. From the scrapbook of Barbara Ann Graves; used with permission.

13. Greene T. Missing couple are found in submerged car. Unknown newspaper, 1981 Jan 24. Unknown page. From the scrapbook of Barbara Ann Graves; used with permission. 